\title{
Building the capacity for community food work: The geographic distribution of USDA Community Food Projects Competitive Grant Program grantees
}

\author{
Keiko Tanaka, ${ }^{a *}$ Erica Indiano, ${ }^{\mathrm{b}}$ Graham Soley, ${ }^{\mathrm{c}}$ and Patrick H. Mooney ${ }^{\mathrm{d}}$ \\ University of Kentucky
}

Submitted August 28, 2014 / Revised January 12 and January 26, 2015 / Accepted January 27, 2015 /

Published online May 21, 2015

Citation: Tanaka, K., Indiano, E., Soley, G., \& Mooney, P. H. (2015). Building the capacity for community food work: The geographic distribution of USDA Community Food Projects Competitive Grant Program grantees. Journal of Agriculture, Food Systems, and Community Development, 5(3), 97-111. http://dx.doi.org/10.5304/jafscd.2015.053.006

Copyright (C) 2015 by New Leaf Associates, Inc.

\begin{abstract}
The U.S. Department of Agriculture's Community Food Projects Competitive Grants Program, or USDA CFPCGP, supports community efforts to address food system issues. Over the last 15 years the program has funded diverse community-based projects across the nation, including youth education programs on healthy eating, farm-to-table initiatives, and community food assessments. In
\end{abstract}

a $*$ Corresponding author: Keiko Tanaka, Department of Community and Leadership Development, University of Kentucky; 500 Garrigus Building; Lexington, Kentucky 405460215 USA; ktanaka@,uky.edu

b Department of Community \& Leadership Development, University of Kentucky; 500 Garrigus Building; Lexington, Kentucky 40546 USA.

c Department of Agricultural Economics, University of Kentucky; 337 Charles E. Barnhart Building; Lexington, Kentucky 40546 USA.

d Department of Sociology, University of Kentucky; 1537

Patterson Office Tower; Lexington Kentucky 40506 USA. this initial study, we endeavor to understand the contribution of the CFPCGP in building a community's capacity to address its own challenges for food security. To analyze funding patterns of the CFPCGP program between 1996 and 2012, we used the websites of the CFPCGP and the WhyHunger Network to identify 420 competitive grant applications successfully funded by this grant program. In this paper we present findings on the geographical distribution of successful applicants and the common objectives of these projects. All but three states had successful applicants. We found considerably uneven (disproportionate to population) distribution of successful grantees

\footnotetext{
Author Notes

This project was supported by a grant from the University of Kentucky College of Agriculture, Food and Environment. Earlier versions of this paper were presented at the 2014 Annual Meeting of the Southern Rural Sociological Association Meeting in Dallas, Texas, and the 2014 National Conference on Undergraduate Research in Lexington, Kentucky.
} 
among 50 states and U.S. territories, as well as among the four USDA Sustainable Agriculture Research and Education (SARE) regions (Northeast, North Central, South, and West). Organizations and cities receiving multiple grants tended to be located in the metropolitan Northeast or West. Training, education, and gardening are common activities proposed in the funded projects. "Lowincome" residents in the community are identified as the target group for nearly one third of the funded grants. We discuss key implications of our findings and offer suggestions for building the capacity of limited-resource communities and organizations to successfully compete for CFPCGP funding.

\section{Keywords}

community food work, food security, community development, federal funding, food localization movement, regional disparity

\section{Introduction}

Food brings people together. Few celebrations or ceremonies in our lives can proceed without food. Yet food also divides people into categories based on class, status, gender, religion, race, ethnicity, ideology, etc. Enormous inequalities persist in the United States among individuals and communities in terms of access to affordable, culturally, and nutritionally adequate food. The USDA Community Food Project Competitive Grant Program (CFPCGP) is intended in part to ameliorate those inequalities. This paper considers how the funding of this program is distributed among organizations, cities, and regions in the United States.

In 2013, an estimated $14.3 \%$ of U.S.

households were food insecure, or lacked "access to enough food for an active, healthy living" for all household members (Coleman-Jensen, Gregory, \& Singh, 2014). One in five children was estimated to be food insecure and did not know where his or her next meal was coming from (Coleman-Jensen et al., 2014). In 2012, 83\% of 51 million eligible individuals participated in the Supplementary Nutrition Assistance Program (SNAP) (Eslami, 2014). Feeding America estimates that in 2014, 46.5 million individuals were served by its network of food banks (Weinfield, Mills, Borger, Gearing,
Macaluso, Montaquila, \& Zedlewski, 2014). Even with assistance, 23.5 million Americans live in food deserts, experiencing difficulty accessing healthy food at a reasonable price (Ver Ploeg, Breneman, Dutko, Williams, Snyder, Dicken, \& Kaufman, 2012).

Within the last decade, the number of community-based initiatives devoted to addressing food insecurity has grown dramatically (Winne, 2008). Such terms as food deserts, food miles, "know your farmer, know your food," and farmto-table have become part of an everyday lexicon for many people. Food has become a critical arena in which we have come to reflect on ourselves, our community, and the economy by asking: What constitutes a good food system? How do we build such a food system in our own community?

Our research project focuses on community efforts to build good food systems. In particular, we examine the role of the USDA CFPCGP in facilitating concerned citizens, activists, and professionals to build capacity to define and address food-security challenges in their own communities, or what we call in this paper community food work. In this paper we address the questions: (1) Who are the successful grantees of the USDA CFPCGP? (2) Where are they located? (3) What kind of activities do they propose to implement through their projects? By asking these questions, we aim to explore the geographic distribution of successful grants and highlight the critical role that federal competitive grant programs may play in shaping community food work in the United States.

Below we will first briefly discuss the increased significance of community food work in recent years. Then we present our initial findings on the key trends and characteristics among the grant applicants who successfully competed for CFPCGP grants between 1996 and 2012. Finally we discuss some implications of these findings, provide suggestions for improving the CFPCGP, and conclude by laying out our plan for further analysis in this research project.

\section{Community Food Work}

The level of a nation's economic development or social progress is often tied to its capacity to feed its population (Braudel, 1992a, 1992b, 1992c; 
Busch \& Lacy, 1984; Sen, 1983; also by Food and Agriculture Organization of the United Nation's Committee on World Food Security, available at http://www.fao.org/cfs/cfs-home/en/). The term community food work is often used to describe the work involving the improvement of food security through community-based strategies. Today this includes a wide range of activities by various types of organizations, such as food banks, soup kitchens, public programs supporting food access (e.g., SNAP, school feeding programs), and healthy-food advocacy groups.

Yet the history of public interventions in ensuring food security in the U.S. population is relatively short (Poppendieck, 1999). Some of the key public programs for feeding, e.g., the first pilot food stamp program, started in the 1930s in response to the Great Depression. The National School Lunch Program (Poppendieck, 2011) and victory gardens were promoted as a part of the nation's war effort during the two war periods to feed those who remained in the homeland. Many of the contemporary programs with which we are familiar today, e.g., the food stamp program (which became SNAP), grew out of community food work associated with the War on Poverty in the 1960s (Poppendieck, 1999; USDA-FNS, 2013).

Within the agrifood studies literature, the current community food security movement is understood as a convergence of two interrelated yet distinct social-movement sectors calling for an alternative food system (Allen, 2004; Constance, Renard, \& Rivera-Ferra, 2014; Goodman, DuPuis, \& Goodman, 2014). One sector emphasizes the goal of transforming agriculture to use more environmentally, economically, and socially sustainable production by fostering more ecologically sustainable farming practices, capturing high added value to maintain commercially vibrant farm enterprises, and enhancing the quality of life for farm families (National Research Council [NRC] Committee on Twenty-First Century Systems Agriculture, 2010). This group tends to be made up of organizations whose members are largely farmers and advocates for family farming. These organizations promote direct linkages between farmers and consumers through such marketing arrangements as community supported agriculture
(CSA), farmers markets, and institutional purchasing (e.g., farm-to-school, farm-to-hospital, consumer cooperatives) to establish a localized food system. In addition, some organizations advocate for production practices and institutional arrangements for socially just food systems, such as fair labor arrangements, socially responsible production practices, and ethical treatments of animals.

The priority of the other social movement sector focuses on food consumption by advocating for the need to improve consumers' access to healthy, nutritious, and culturally adequate food at affordable prices. This latter priority is highly fragmented in comparison to the sustainable agricultural production priority. Some of the organizations pursuing this priority were formed between the mid-1960s and early 1980s in anti-poverty and anti-hunger work, including provision of emergency food assistance (e.g., food banks, food pantries, soup kitchens). These organizations tend to focus their effort on food access among community members with limited resources. On the other hand, a newer subgroup under the food consumption priority that has proliferated in the last two decades tends to emphasize improving the adequacy of food that is available to all community members and their health behaviors (see Winne, 2008).

Although these two sets of prioritiessustainable agricultural production and improved food consumption - are not mutually exclusive, they can be considered as a "wicked problem" (Nelson \& Stroink, 2014). While family farmers hope to capture premiums for their harvest, urban consumers want to be able to afford these products. On the one hand, the food consumption priority is oriented toward the needs of urban consumers, thus paying less attention to sustainable farming and food production activities. On the other hand, the sustainable agriculture/food localization priority tends to attract highly educated and/or economically privileged consumers. This group tends to understate the structurally generated social inequalities that often exclude certain groups of consumers (e.g., racial and ethnic minorities, the poor) from participating in the localized food system (see Alkon \& Agyeman, 2011).

Institutional purchasing of fresh fruits and 
vegetables through the farm-to-school/college/ hospitals, gleaning for redistribution at food pantries and soup kitchens, and establishing food hubs are examples of economic approaches that link the needs of farmers and consumers. These approaches create a food system that consists of short chains between farmers and consumers while taking advantage of economies of scale. Examples of political approaches include establishing food policy councils at the local, county, or state level that may include creating a local-food coordinator position in the local government (see Winne, 2008). Both the economic and political approaches are intended to create a forum to bring together representatives from diverse types and sectors of the food system to collaborate in the community work through the political process (Burgan \& Winne, 2012). Our analysis in another research project on the food policy council movement suggests that the agriculture sector is not well represented in many food policy councils at the local level. If represented, it tends to be limited to a rather narrow range of agricultural interests (Mooney, Tanaka, \& Ciciurkaite, 2014).

As a grant program of the USDA, the CFPCGP explicitly encourages grant applicants to demonstrate how their project contributes to connecting farmers and consumers. The proposed projects need to lead to a sustainable institutional mechanism to address food security challenges in the community beyond the expiration of the grant. This program aims to address food insecurity issues in low-income communities by funding projects that will "unite the entire food system, assessing strengths, establishing linkages, and creating systems that improve self-reliance over food needs" (USDA NIFA, 2010, para. 4). Below we examine the programs that were successful in receiving grants under the USDA CFPCGP.

\section{USDA Community Food Project Competitive Grant Program}

The CFPCGP is established under legislative authority of the Food Stamp Act of 1977 (PL 108269; see 7 U.S.C. 2034). In 1996, the Federal Agriculture Improvement and Reform Act (PL 104-127-APR. 4 1996) authorized the funding of this grant program to encourage self-reliance in building food security in low-income communities. The Farm Security and Rural Investment Act of 2002 (PL 107-171) reauthorized the program. Then the legislative authority was amended by the Food and Nutrition Act of 2008 as well as Section 4402 of the Food, Conservation, and Energy Act (FCEA) of 2008 (PL 110-246). According to the 2014 CFPCGP request for applications (USDA NIFA, 2014a):

The primary goals of the CFPCGP are to:

- Meet the food needs of low-income individuals through food distribution, community outreach to assist in participation in federally assisted nutrition programs, or improving access to food as part of a comprehensive service;

- Increase the self-reliance of communities in providing for the food needs of communities;

- Promote comprehensive responses to local food access, farm, and nutrition issues; and

- Meet specific state, local or neighborhood food and agricultural needs including needs relating to:

○ Equipment necessary for the efficient operation of a project;

o Planning for long-term solutions: or

$\circ$ The creation of innovative marketing activities that mutually benefit agricultural producers and low-income consumers. (p. 23)

The program offers three types of grants, including: (1) Community Food Projects (CFP), (2) Planning Projects (PP), and (3) Training and Technical Assistance (T\&TA) Projects. Due to the lack of detailed information about each funded grant, we were unable to consider differences among these three grant types in the present analysis. Regardless of the type of grants, the CFPCGP aims to facilitate capacity building of low-income, limited-resource communities.

Any private, nonprofit organizations as well as public food service providers and tribal organizations are eligible to apply for a grant under this program. However, the proposal must demonstrate that the lead organization has experience with 
"community food work, particularly concerning small and medium-size farms, including the provision of food to people in low-income communities and the development of new markets in low-income communities for agricultural producers," competence in successfully implementing a project, and willingness to share the findings and lessons from the project with other practitioners and researchers in community food work (USDA NIFA, 2014a, p. 9).

The program specifically encourages diverse types of organizations (e.g., academic, nonacademic, public, private, business, nonprofit) from multiple sectors in the food system to build partnerships and share resources and expertise. Through strong collaborations among stakeholders in the community, each project is expected to generate sustainable solutions to what they collectively consider to be challenges to food security in their own community while also developing knowledge, skills, and institutional frameworks necessary for building a community-based, local food system according to the vision of the project team (USDA NIFA, 2014a).

Because of the emphasis on integrative approaches to addressing food, farm, and nutrition issues, the CFPCGP becomes a space for facilitating "a national incubator in which comprehensive, but relatively small-scale, food system innovation is taking place community by community" (Maretzki \& Tuckermanty, 2007, p. 335). Pothukuchi found that CFPCGP projects between 1999 and 2003 contributed to making "healthy food more available in low-income communities; enabled youth and adults alike to gain skills in food production and marketing; supported the development of local jobs and food-related businesses; and developed a host of innovative approaches to problems linking food, agriculture, and nutrition" (2007, p. 5). Our aim in this paper is not to evaluate the validity of these claims or efficacy of the grant program. Instead, we ask who are successful grantees of the CFPCGP, where are they located, and what activities do they propose to implement? Answering these questions will help us understand how a federal competitive grant program such as the CFPCGP shapes community food work in this country.

\section{Methods}

To collect the information on the successful grantee applicants, we carried out an exhaustive search of publicly available data and identified two critical websites. The USDA CFPCGP website provides key information about funded projects between 1996 and 2012. The WhyHunger Network website (2014) also includes a database of the projects funded between 1996 and 2012. We identified 420 CFPCGP projects. The amount of information readily available from these sources varies tremendously depending on the grant year. For example, a list of the funded projects for the year of 2004 was published in the form of a press release (USDA Office of Communications, 2004). We also used the decennial report on the CFPCGP, Healthy Food, Healthy Community, for information on the funded grants between 1996 and 2006 (Community Food Project $10^{\text {th }}$ Anniversary Production Team, 2007). Although several successful grant applicants may be missing from the USDA and WhyHunger Network data sets, we assume that no systematic bias exists in the missing data.

For each CFPCGP project we recorded the following variables: the grant year, the location of the lead organization, the grant amount (which ranged from US $\$ 6,560$ to US $\$ 300,000$ ), the objective or mission statement of the project, the contact name for the grantee, the email of the contact person, and the web address of the project. We created a spreadsheet to identify any patterns in the historical trend of grant funding, including: the number of grants per state, the number of institutions that received multiple grants, and common themes and activities.

For most projects funded between 1996 and 1999, we were unable to locate anything beyond the title and lead organization of each project, and therefore excluded those from the analysis of funding amounts and common themes and activities. We also were unable to find any mission or objective statements for some projects funded in the years of 2000 and 2006 . Thus 359 projects out of the original 420 projects were used for analysis of thematic patterns.

To examine the geographical distribution of grants, we used the four Sustainable Agriculture 
Research and Education (SARE) regions of the United States, a modified version of the federal regions designated by the U.S. Census Bureau and commonly used by the USDA (see Map 1). These are defined as (USDA SARE, n.d.):

- North Central Region: Illinois, Indiana, Iowa, Kansas, Michigan, Minnesota, Missouri, Nebraska, North Dakota, Ohio, South Dakota, and Wisconsin;

- Northeast Region: Connecticut, Delaware, Maine, Maryland, Massachusetts, New Hampshire, New Jersey, New York, Pennsylvania, Rhode Island, Vermont, and West Virginia;

- Southern Region: Alabama, Arkansas, Florida, Georgia, Kentucky, Louisiana, Mississippi, North Carolina, Oklahoma,
Puerto Rico, South Carolina, Tennessee, Texas, U.S. Virgin Islands, and Virginia; and

- Western Region: Alaska, American Samoa, Arizona, California, Colorado, Guam, Hawaii, Idaho, Micronesia, Montana, Nevada, New Mexico, Oregon, Utah, Washington, and Wyoming.

To examine the patterns in what the successful grantees proposed to do, we used NVivo, a software program for qualitative data analysis, to identify common words and phrases used in the statement of the project objectives and approaches in 359 projects funded between 1996 and 2012. We then categorized these words and phrases by project to examine the geographical place of the proposed community food work, the type of activities, and the target groups. Because we used project

\section{Map 1. Regions of the United States as Defined by the U.S. Department of Agriculture (USDA) Sustainable Agriculture Research and Education (SARE) Program and Used in this Study}

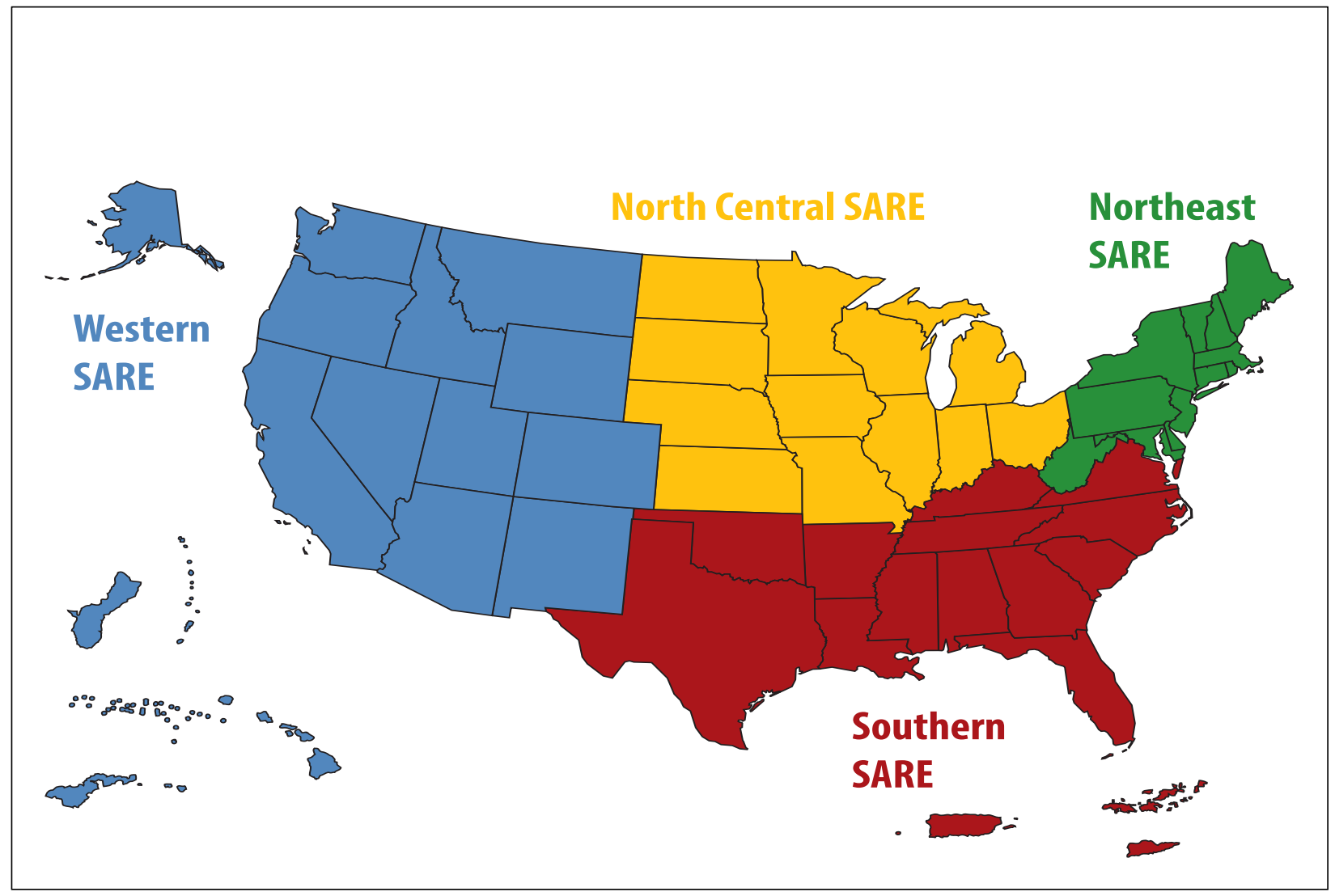

Reprinted with permission from SARE's four regions (http://www.sare.org/About-SARE/SARE-s-Four-Regions). Citation of SARE materials does not constitute SARE's or USDA's endorsement of any product, organization, view, or opinion. For more information about SARE and sustainable agriculture, see http://www.sare.org 
summaries, which are publicly available, we did not analyze in depth how words (e.g., business, gardening) and phrases (e.g., access to the market) that appeared frequently were intended by these different organizations in diverse projects.

There are several limitations to our analysis. First, we used the address of the performing institution as the location of the project. This was problematic because many of them are located in urban areas even though their activities serve the needs of rural communities and residents. Another problem with the use of the organization's address was differentiating between those nonprofit organizations that have a national or regional scope (such as the Community Food Security Coalition (CFSC) and Janus Youth Program) and those with a scope of work within a single state. We do not know the precise number of the grant recipients that work beyond the state level. We reviewed the websites of multiple grant recipients to understand the geographical scale of their organizational activities.

Second, the project summaries preclude assessment of the extent to which the proposed activities were completed and generated the expected outputs and outcomes. Although they were extremely useful, the evaluative reports on the CFPCGP published by the CFSC (e.g., Community Food Project $10^{\text {th }}$ Anniversary Production Team, 2007; Pothukuchi, 2007; Tauber \& Fisher, 2002) provided detailed information about only those projects that were considered to be successful and exemplary. Moreover, these project summaries and descriptions did not include a list of collaborating organizations and individuals. We therefore do not know how many performing organizations are involved in multiple CFPCGP projects in their state or region. As discussed below, our future analysis will include the annual reports and final project reports from several projects selected for case study.

Third, this analysis did not taken into account historical transformations of the grant program. The amount appropriated for the CFPCGCP as well as the priority areas and eligible activities have changed over the 15 -year period. Our future analysis will investigate the transformations of the grant program in relation to changes in the community food security movement in the U.S.

\section{Results}

Between 1996 and 2012, the USDA CFPCGP funded 420 projects. As shown in Figure 1, in the first three years of the program the number of grants funded was very small $(n=13)$; the total federal funding allocated to the program appears to be very small. Since 2002, the federal appropriation to the program seems to be more or less stable at around US $\$ 4.7$ million, except for the funding year of 2009. During the 10-year period of 2002 to 2012 (excluding the anomalous year of 2009), 27 projects on average were funded annually. We were unable to explain why the funding allocation for the year of 2009 doubled. This section presents the geographical patterns and common themes of these projects.

\section{Geographical Distribution of Grant Funding} Forty-seven states received at least one CFPCGP grant. Kentucky, New Hampshire, and Utah have never received a grant. American Samoa also received one grant and Washington, D.C., received three. Although Washington, D.C., is technically not part of any of the SARE regions, we included those grants in our analysis of the geographical distribution as part of the Northeast SARE region. Table 1 shows the 10 states with the most grants funded by the program over the 15-year period. All these states hold reputations as trend-setters in the sustainable agriculture and community food security movement. They are all located in either the Northeast or Western regions of the United States.

There are enormous differences among the "food environments" of these 47 states (see the USDA ERS Food Environment Atlas, http://www.ers.usda.gov/data-products/foodenvironment-atlas.aspx) as well as among their agroecological conditions for farming, sociocultural history of community-based activism, and the these factors. To better grasp the regional distribution of CFPCGP grants, the data are grouped into the four SARE regions. Between 1996 and 2012, the Western region received the most grants, with 160 out of 420 grants (39\%), followed by the Northeastern region, with 112 grants $(27 \%)$, the North Central region with 76 grants $(18 \%)$, and the Southern region with 69 grants $(16 \%)$. Considering that both the North- 
Figure 1. Number and Amount (in US\$) of CFPCGP Grants per Year, 1996-2012

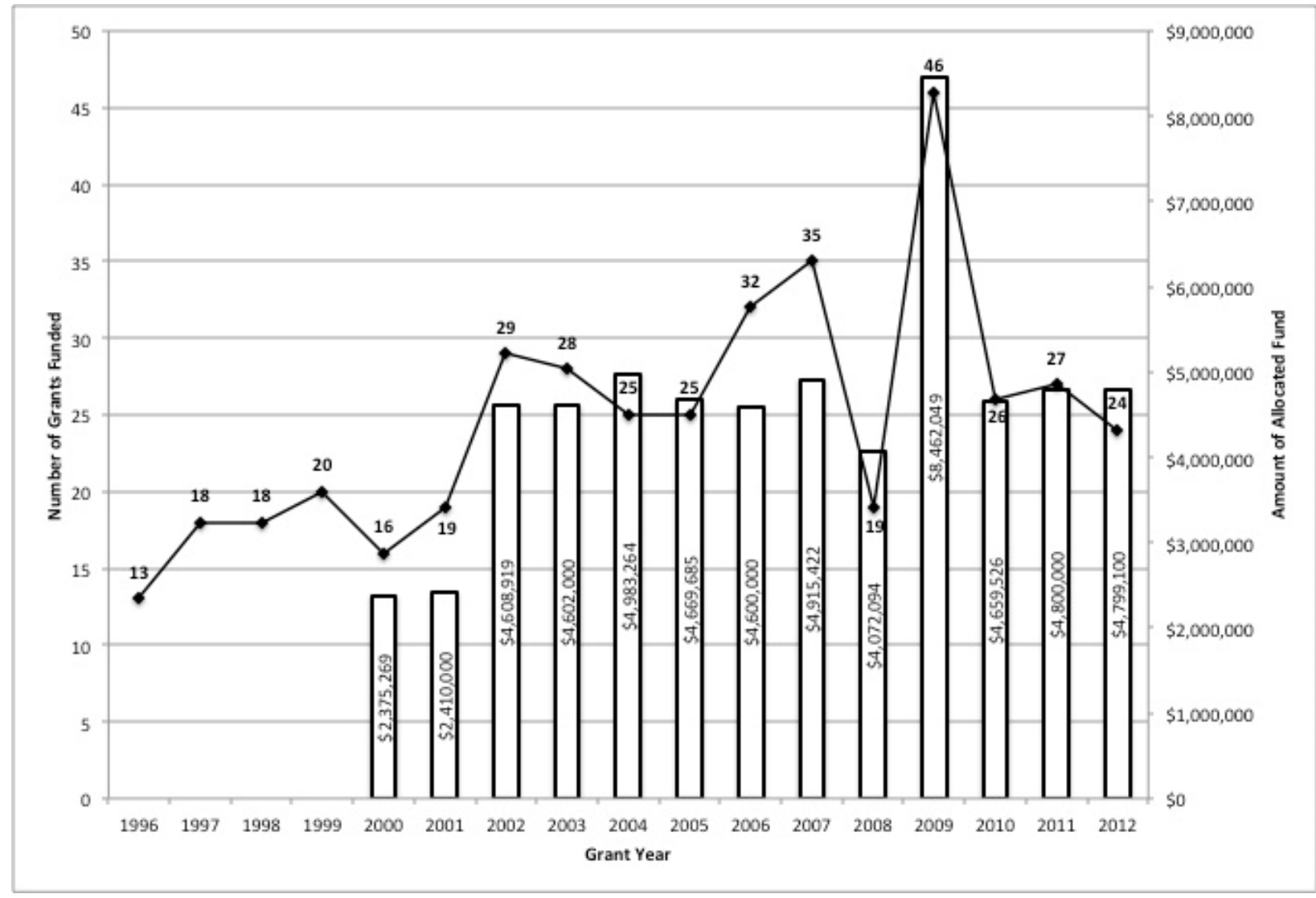

eastern and Western regions include states known for their vibrant sustainable agriculture and community food security movements, this regional discrepancy may not be surprising. Table 2 compares the distribution of grants by region over four time periods. As indicated in the table, the Southern region has a substantially greater population than the other regions (U.S. Census Bureau, 2014), but received the least number of grants in each period. Compared with other regions, the Southern region has much higher rates of obesity and household food insecurity (Tanaka, Mooney, \& Wolff, 2014). This distribution of CFPCGP grants among the four regions did not change substantially over time.

Even after the sustainable agriculture and community food security movement began to spread across the U.S. from the two coasts, the Western region received more than twice the amount of funding from the CFPCGP than the North Central or Southern regions.
Distribution of Multiple-Grant Recipient Organizations and Cities

Among the 420 grants, 260 grants $(62 \%)$ were given to first-time recipients. The remaining 140 grants were distributed among 58 organizations,

Table 1. Top 10 States by Number of USDA CFPCGP Grants, 1997-2012

\begin{tabular}{ll}
\hline State & Number \\
\hline California & 59 \\
\hline New York & 28 \\
\hline Massachusetts & 26 \\
\hline Oregon & 22 \\
\hline Maine & 17 \\
\hline New Mexico & 16 \\
\hline Arizona & 16 \\
\hline Pennsylvania & 14 \\
\hline Wisconsin & 14 \\
\hline Washington and Minnesota (tied) & 13 \\
\hline
\end{tabular}


Table 2. Distributions of USDA CFPCGP Grants and Population by Region, 1997-2012

\begin{tabular}{|c|c|c|c|c|c|c|c|c|c|}
\hline & & \multicolumn{3}{|c|}{ Population (1,000s) } & \multicolumn{5}{|c|}{ Grants } \\
\hline & & 1990 & 2000 & 2010 & $\begin{array}{c}1997- \\
2000\end{array}$ & $\begin{array}{c}2001- \\
2004\end{array}$ & $\begin{array}{c}2005- \\
2008\end{array}$ & $\begin{array}{c}2009- \\
2012\end{array}$ & Total \\
\hline \multirow{2}{*}{ Northeast } & $N$ & 58,658 & 62,055 & 64,443 & 23 & 30 & 24 & 36 & 113 \\
\hline & $\%$ & $24 \%$ & $22 \%$ & $21 \%$ & $27 \%$ & $30 \%$ & $22 \%$ & $29 \%$ & $27 \%$ \\
\hline \multirow{2}{*}{ North Central } & $N$ & 59,669 & 64,393 & 66,927 & 16 & 21 & 22 & 16 & 75 \\
\hline & $\%$ & $24 \%$ & $23 \%$ & $22 \%$ & $19 \%$ & $21 \%$ & $20 \%$ & $13 \%$ & $18 \%$ \\
\hline \multirow{2}{*}{ West } & $N$ & 52,784 & 63,198 & 71,946 & 30 & 35 & 45 & 53 & 163 \\
\hline & $\%$ & $21 \%$ & $22 \%$ & $23 \%$ & $35 \%$ & $35 \%$ & $41 \%$ & $43 \%$ & $39 \%$ \\
\hline \multirow{2}{*}{ South } & $N$ & 77,607 & 91,776 & 105,430 & 16 & 15 & 20 & 18 & 69 \\
\hline & $\%$ & $31 \%$ & $33 \%$ & $34 \%$ & $17 \%$ & $14 \%$ & $18 \%$ & $15 \%$ & $16 \%$ \\
\hline Total & $N$ & 248,718 & 219,367 & 244,302 & 85 & 101 & 111 & 123 & 420 \\
\hline
\end{tabular}

Sources: Mackun \& Wilson, 2011; Perry \& Mackun, 2001.

including 35 organizations with 2 grants, 12 organizations with 3 grants, 8 organizations with 4 grants, Southside Community Land Trust (Providence, Rhode Island) with 5 grants, Janus Youth Program (Portland, Oregon) with 6 grants, and Community Food Security Coalition (Portland, Oregon, and Venice, California) with 17 grants. Some of the multiple-grant recipient organizations work beyond the state level. Table 3 lists the organizations that received four or more grants.

As mentioned above, the CFSC was a national organization composed of over 300 member organizations who focus on various types of community food work, including sustainable agriculture, hunger and food security, food sovereignty, and farm-to-institution, until it dissolved in 2012. World Hunger Year (currently known as WhyHunger Network) and First Nations Development Institute are also national organizations. Although Farm to Table emphasizes building the capacity for community food work in New Mexico, it "works at the local, regional and national levels through innovative, community-driven programs and strong partnerships" (Farm to Table, n.d., para. 1). Janus Youth Program, founded in 1972, provides community-based residential care for homeless youth and substance abusers in Oregon and Washington. Although not listed in Table 3,
Southern Sustainable Agriculture Working Group (Southern SAWG; $n=3$ ) is a regional organization that operates in 13 Southern SARE states.

These national and regional organizations often become a hub for nonprofit organizations to collect resources-e.g., data, potential partners, best management practices in community food work - necessary for designing projects and writing grant proposals. For example, through its annual meetings and regional workshops, the CFSC and the Southern SAWG offer training for their member organizations or individuals to design community-based food projects and assist them in developing fundable proposals. The CFSC conducted evaluation studies to identify the best practices among CFPCGP-funded projects and disseminated a guidebook for designing and implementing successful community food projects (e.g., Community Food Projects 10th Anniversary Production Team 2007; Pothukuchi, 2007; Pothukuchi, Joseph, Burton, \& Fisher, 2002; Tauber \& Fisher, 2002).

Next, we examined how many cities and townships in the United States received multiple grants from the CFPCGP to tackle their food challenges. Between 1996 and 2012, 237 cities received at least one CFPCGP grant; 73 of these cities received multiple grants. Top recipient cities 
Table 3. Lead Organizations with Multiple USDA CFPCGP Grants, 1997-2012

\begin{tabular}{llc}
\hline Organization Name & Organization Location & $\begin{array}{c}\text { Number of Grants } \\
\text { Received }\end{array}$ \\
\hline Community Food Security Coalition & Portland, Oregon, \& Venice, California & 17 \\
\hline Janus Youth Program & Portland, Oregon & 6 \\
\hline Southside Community Land Trust & Providence, Rhode Island & 5 \\
\hline Community Teamwork & Lowell, Massachusetts & 4 \\
\hline Cultivating Community & Portland, Maine & 4 \\
\hline Farm to Table & Santa Fe, New Mexico & 4 \\
\hline First Nations Development Institute & Fredericksburg, Virginia, \& Longmont, Colorado & 4 \\
\hline Growing Power, Inc. & Gainesville, Florida & 4 \\
\hline Nuestras Raices & Milwaukee, Wisconsin & 4 \\
\hline Youth and Farm Market Project & Holyoke, Massachusetts & 4 \\
\hline
\end{tabular}

are Portland, Oregon, with 17 grants; New York City, with 13 grants; Philadelphia, Pennsylvania, with 11 grants; Los Angeles, California, with 8 grants; Milwaukee, Wisconsin, and Santa Fe, New Mexico, with 7 grants each; and Lowell, Massachusetts, San Francisco, and Seattle, with 6 grants each. Because 58 organizations received more than one grant as noted above, we ranked the cities with multiple grants based on the number of distinct organizations being funded by the CFPCGP. While Portland, Oregon, received the largest number of grants with a total of 17 , the largest number of organizations funded by the CFPCGP was in Philadelphia $(n=10)$, followed by New York with 8 organizations; Los Angeles with 7 organizations; and New Orleans, Portland, Oregon, San Francisco, and Seattle with 5 organizations. Although Lowell, Minneapolis, Providence, Rhode Island, and Venice, California, received 5 or more grants, these grants went to one or two organizations.

Common Activities and Target Groups, 1996-2012

Of 420 projects funded between 1996 and 2012, we were successful in obtaining objective statements for 359 projects (see the Methods section above). Project objectives were used to identify common activities as well as target groups
Table 4. Common Activities and Target Groups, 1996-2012 ( $N=359)$

\begin{tabular}{|c|c|c|c|c|c|}
\hline Activity & $n$ & $\%$ & Target Group & $n$ & $\%$ \\
\hline Gardening & 70 & 19.5 & Low income & 122 & 34.0 \\
\hline Training & 62 & 17.3 & Farmers & 59 & 16.4 \\
\hline Education & 54 & 15.0 & Youth & 46 & 12.8 \\
\hline Planning & 46 & 12.8 & Schools & 38 & 10.6 \\
\hline Networking & 27 & 7.5 & & & \\
\hline Policy work & 23 & 6.5 & & & \\
\hline
\end{tabular}

among these grants. As shown in Table 4, gardening is the most common activity proposed by successful applicants to this grant program, mentioned in 70 out of 359 projects. As expected, training and education are also common activities proposed by CFPCGP grantees, while planning, networking, and policy work are other commonly proposed activities. Improved access to market $(n=89)$, business $(n=33)$, and distribution $(n=22)$ frequently appeared as goals through these activities. Besides gardening, nutrition $(n=43)$ is often included as an area for skill development.

In accordance with the objective of this grant program, which is to address food insecurity issues, 122 of 359 funded grantees explicitly claim "lowincome" populations in their community as their target group for their proposed activities. Yet other groups such as farmers, youth, and schools were included as important components in addressing food insecurity in the community (see Table 4). 


\section{Discussion}

Receiving federal funding for a project can have significant effects on a community. Since its inception, the CFPCGP has become a critical source of funding for many nonprofit, community-based organizations to develop and pursue projects to transform both the community's infrastructure and residents' capacity for food access in the community. The above findings show clear patterns in the distribution of CFPCGP grants. Metropolises in the Western and Northeastern regions are more likely to be funded by this program than those in the Southern and North Central regions. As pointed out below, these regional discrepancies require more comprehensive analysis to identify key organizational and human resource factors that lead to success in this highly competitive grant program.

On the one hand, our findings suggest that federal funding indeed plays an important role in developing and shaping leadership in the community food security movement. As pointed out above, the social movement surrounding community food security grew in the last three decades as two distinct, though overlapping, sets of social movements: one for sustainable agriculture and food localization, and the other for anti-poverty and anti-hunger (Allen, 2004). Among recipients of multiple grants, WhyHunger Network and Janus Youth Program were established in the 1970s as anti-hunger organizations, while organizations such as CFSC, Farm to Table, and the Southern SAWG began in and after the 1990s as the sustainable agriculture and food localization movement grew. Over the last 25 years, these organizations have played a leading role in the community food security movement.

On the other hand, our current data cannot answer the question: "Are those multigrant recipient organizations receiving funding because they are organized, or are they organized because they are funded by these federal grants?" Until its closure in 2012, the CFSC acted as a nongovernmental partner of the CFPCGP by disseminating information about the program, training grantseeking organizations to design fundable projects for the program, and carrying out evaluation of the grant program (Pothukuchi, 2007). WhyHunger
Network maintains a database of the funded projects of the CFPCGP to help community-based organizations building partnerships with other organizations in community food work.

This "chicken-and-egg" question of resource mobilization requires further analysis for three reasons. First, the CFPCGP seeks to address public issues such as hunger, food insecurity, and obesity that have causes rooted in the historically and spatially embedded inequality of resource access among various groups of the American population. This small grant program creates a market in which community-based organizations must compete for grants, each of which is less than US $\$ 300,000$ over three years, and assume responsibility for addressing food insecurity in their communities. In this market, experienced and well-resourced organizations tend to be more competitive. The quandary is that this may exclude some of the very communities that need to build capacity and gain experience in community food work.

Grant requirements for cost-matching and detailed accounting advantage certain types of organizations while constraining others, and therefore potentially contribute to furthering the discrepancy in the capacity for community building among these organizations. As the federal funding for nondefense programs continues to shrink, it is critical to identify successes and failures in resource sharing among diverse organizations within the community to address their food challenges.

Second, the CFPCGP reflects a tension within the community food security movement between the two social movement sectors, namely those who prioritize the goals of building sustainable agriculture and localizing the food economy versus those who prioritize the goal of addressing poverty and hunger in the community. As we have emphasized, these two sets of priorities can be conflicting. Farmers and other actors involved in food production wish to receive fair prices for their food products and a return for their labor as protection of their own economic security. Urban consumers, particularly those with limited resources, wish to access fresh fruits, vegetables and other healthy food products at affordable prices. Answering the chicken-and-egg question regarding resource mobilization helps us understand the role of a 
USDA agency in managing the complex and interdependent relationships between producers and consumers and creating opportunities for linking these interests to improve the quality of the food system in the community.

Finally, the CFPCGP raises a concern regarding its responsibility to address the geographical disparity in food security. As Tanaka, Mooney, \& Wolff (2014) point out, high rates of food insecurity are more prevalent among rural (or nonmetro) households than urban and suburban (or metro) households as well as households in the Southern and Western regions than those in the North Central and Northeast. Our analysis suggests that thus far the CFPCGP has not been able to address the unequal spatial distribution of economic, political, social, and cultural capital that is associated with high food insecurity and obesity rates. Understanding the lower rates of CFPCGP funding in Southern states will help us identify key factors that enable and constrain certain communities in building their capacity to address their community food security issues.

Nevertheless, the contribution of the CFPCGP to building community capacity for food localization is undeniably valuable; we hope the program will receive increased funding. Through 420 grants, 318 organizations with diverse goals and memberships were funded to examine the state of food security and to design and implement a project to reduce food gaps and food deserts in their community. By encouraging grant applications to explicitly show the contribution to building connections between farmers and consumers, this grant program creates a space for collaborations and coalitions among various groups and individuals working in community food work. We therefore emphasize the CFPCGP's potential in building a robust bridge between the sustainable agriculture and food localization camps within the community food security movement.

Based on the results of our analysis, we make the following three recommendations.

First, with the loss of the CFSC as the nation's leading coalition organization representing over 300 community food work organizations, the CFPCGP needs to consider strategies for disseminating information and resources about the grant program, training smaller community-based organizations to design a fundable project, and evaluating the efficacy of the community food work among these organizations. Under the category of Training and Technical Assistance (T\&TA) Projects, the CFPCGP began providing larger, multiyear grants to well-established organizations for these purposes, as well as evaluating and improving the effectiveness of this grant program. The impact of creating this new funding category demands further analysis. However, we recommend that the T\&TA grants be distributed strategically to address regional discrepancies in the capacity for community food work.

Second, we suggest that the USDA National Institute for Food and Agriculture (NIFA) consider the SARE program as a potential model for decentralizing the CFPCGP. Based on our analysis, the CFPCGP seems to fall short in its ability to address regionally specific needs in community food work. Unfortunately, the funding level of the CFPCGP is considerably smaller than SARE. In the 2014 fiscal year, SARE's budget is about US $\$ 23$ million while the CFPCGP is around US $\$ 5$ million (USDA NIFA, 2014b). It is therefore unrealistic for the CFPCGP to be run by regional offices as SARE is. To maintain the emphasis on farmerconsumer connections, the CFPCGP should remain independent and autonomous from SARE. We recommend the creation of an advisory board with regional representatives who work with the review panel in recommending funding allocations.

Finally, while advocating regional decentralization of funding, we also suggest the coordination of funding between federal agencies for community food work. Under the USDA NIFA, a few grant programs support projects to localize the food economy and facilitate healthy eating. The National Institute of Health $(\mathrm{NIH})$ also funds community-based projects to promote healthy eating behaviors. In a given year, many community-based organizations with limited human resources and technical expertise end up spending an enormous amount of time and effort applying for these grants. This fragmentation of federal funding for community food work may contribute to widening a gap among organizations, communities, and regions in addressing their community 
food security challenges. A possible solution may be to create a joint grant program, a collaboration of the NIFA, NIH, and other federal agencies, that provide larger, multiyear grants for statewide coalitions in community food work.

These three sets of recommendations are tentative because further, more nuanced analysis of the CFPCGP is required. In conclusion, we will lay out our plan for future analysis.

\section{Conclusion}

Food should bring individuals in the community together, rather than dividing them. This is the underlying assumption used in the CFPCGP for funding community-based, multisectoral projects that foster self-sufficiency in community food work. In doing so, what role do these and other related federal funding programs play in building the community food security movement across the nation? By focusing on community capacity building for self-sufficiency, how effectively and efficiently is the limited federal funding distributed to enable communities and organizations to address their food security challenges? Under the current political climate of fiscal austerity, answering these questions is critical to identify shortcomings of these federal grant programs and generate recommendations for improving their transformative potential.

This paper is our first step in understanding the role of the CFPCGP in creating better food systems in the United States. Our next two steps include: (1) an historical analysis of transformations in the grant program through the document analysis of project reports and requests for proposals, and interviews with representatives of USDA NIFA, the CFSC, and other major recipient organizations; and (2) case studies of some systematically selected projects to represent critical variables such as spatial scope, urban versus rural focus, and types of activities.

Food is fundamental to our survival as well as to our essence as individuals and members of households, families, communities, and the nation. To improve a federal program that enables us to do community food work is therefore a critical public policy goal.

\section{References}

Alkon, A. H., \& Agyeman, J. (2011). Cultivating food justice: Race, class, and sustainability. Cambridge, Massachusetts: MIT Press.

Allen, P. (2004). Together at the table: Sustainability and sustenance in the American agrifood system. University Park, Pennsylvania: The Pennsylvania State University Press.

Burgan, M., \& Winne, M. (2012). Doing food policy councils right: A guide to development and action. Santa Fe, New Mexico: Mark Winne Associates. Retrieved from http://www.markwinne.com/wp-content/ uploads/2012/09/FPC-manual.pdf

Braudel, F. (1992a). Civilization and capitalism, 15 $15^{\text {th }}-18^{\text {th }}$ century, Volume 1: The structure of everyday life. Berkley, California: University of California Press.

Braudel, F. (1992b). Civilization and capitalism, 15 $15^{\text {th }}-18^{\text {th }}$ century, Volume 2: The wheels of commerce. Berkley, California: University of California Press.

Braudel, F. (1992c). Civilization and capitalism, 15 $15^{\text {th }}-18^{\text {th }}$ century, Volume 3: The perspective of the world. Berkley, California: University of California Press.

Busch, L., \& Lacy, W. B. (1984). Food security in the United States. Boulder, Colorado: Westview Press.

Coleman-Jensen, A., Gregory, C., \& Singh, A. (2014). Household food security in the United States in 2013 (USDA ERS Economic Research Report No. 173). Retrieved from http://www.ers.usda.gov/media/ 1565415/err173.pdf

Community Food Projects 10th Anniversary Production Team. (2007). Healthy food, healthy communities: $A$ decade of community food projects in action. Los Angeles: Community Food Security Coalition.

Constance, D. H., Renard, M.-C., \& Rivera-Ferre, M. G. (Eds.). (2014). Alternative agrifood movements: Patterns of convergence and divergence. Bingley, UK: Emerald Group Publishing.

Eslami, E. (2014). Trends in Supplemental Nutrition Assistance Program participation rates: Fiscal year 2010 to Fiscal year 2012. Alexandria, Virginia: USDA Food and Nutrition Service (FNS). Retrieved from http://www.fns.usda.gov/sites/default/files/ops/ Trends2010-2012.pdf

Farm Security and Rural Investment Act of 2002. Public Law 107-171. 7 USC 7901. Retrieved from http://www.gpo.gov/fdsys/pkg/PLAW107publ171/pdf/PLAW-107publ171.pdf 
Farm to Table. (n.d.). How we work. Retrieved April 30, 2015, from http://www.farmtotablenm.org/aboutus/how-we-work/

Federal Agriculture Improvement and Reform Act of 1996. Public Law 104-127-APR. 4 1996, 7 U.S.C. 7201. Retrieved from http://www.gpo.gov/ fdsys/pkg/PLAW-104publ127/pdf/PLAW104publ127.pdf

Food and Agriculture Organization of the United Nations' Committee on World Food Security. (n.d.). Home page. http://www.fao.org/cfs/cfshome/en/

Food and Nutrition Act of 2008. Public Law 113-79, 7 U.S.C. 2011. Retrieved from http://legcounsel.house.gov/Comps/Food $\% 20$ And $\% 20$ Nutrition $\% 20$ Act $\% 200 f \% 202008$.pdf

Food, Conservation, and Energy Act [FCEA] of 2008. Public Law 110-246, 7 U.S.C. 8701. Retrieved from http://www.gpo.gov/fdsys/pkg/PLAW110publ246/pdf/PLAW-110publ246.pdf

Food Stamp Act of 1977. Public Law 108-269, 7 U.S.C. 2034. Retrieved from http://www.fns.usda.gov/ sites/default/files/PL 88-525a 0.pdf

Goodman, D., DuPuis, E. M., \& Goodman, M. K. (2014). Alternative food networks: Knowledge, practice, and politics. Oxon, UK, and New York: Routledge.

Mackun, P., \& Wilson, S. (2011). Population distribution and change: 2000 to 2010. 2010 Census Briefs (C2010BR-01). U.S. Census Bureau. Retrieved from http://www.census.gov/prod/cen2010/briefs/c20 10br-01.pdf

Maretzki, A. N., \& Tuckermanty, E. (2009). Community food projects and food system sustainability. In C. C. Hinrichs \& T. A. Lyson (Eds.), Remaking the North American food system: Strategies for sustainability (pp. 332-342). Lincoln, Nebraska: University of Nebraska Press.

Mooney, P. H., Tanaka, K., \& Ciciurkaite, G. (2014). Food policy council movement in North America: A convergence of alternative local agrifood interests? In D. H. Constance, M.-C. Renard, \& M. G. Rivera-Ferre (Eds.), Alternative agrifood movements: Convergence and divergence (pp. 229-256). Bingley, UK: Emerald Group Publishing.

National Research Council Committee on Twenty-First Century Systems Agriculture and Board on Agriculture and Natural Resources. (2010). Toward sustainable agricultural systems in the $21^{\text {st }}$ century. Washington, D.C.: National Academies Press.
Nelson, C. H., \& Stroink, M. L. (2014). Accessibility and viability: A complex adaptive systems approach to a wicked problem for the local food movement. Journal of Agriculture, Food Systems, and Community Development, 4(4), 191-206. http://dx.doi.org/10.5304/jafscd.2014.044.016

Perry, M. J., \& Mackun, P. J. (2001). Population change and distribution: 1990 to 2000 (Census 2000 Brief. C2KBR/01-2). U.S. Census Bureau. Retrieved from http://www.census.gov/prod/2001pubs/c2kbr012.pdf

Poppendieck, J. (1999). Sweet charity? Emergency food and the end of entitlement. New York: Penguin Books.

Poppendieck, J. (2011). Free for all: Fixing school food in America. Berkeley, California: University of California Press.

Pothukuchi, K. (2007). Building community food security: Lessons from Community Food Projects, 1999-2003.

Venice, California: Community Food Security Coalition. Retrieved from http://www.jhsph.edu/ research/centers-and-institutes/johns-hopkinscenter-for-a-livable-future/ pdf/projects/FPN/ coomunity food assesment/Building $\% 20$ Community $\% 20$ Food $\% 20$ Security $\% 20$ Lessons \%20Learned.pdf

Pothukuchi, K., Joseph, H., Burton, H., \& Fisher, A. (2002). What's cooking in your food system? A guide to community food assessment. Venice, California: Community Food Security Coalition. Retrieved from http:// foodsecurecanada.org/resourcesnews/resources-research/whats-cooking-yourfood-system-guide-community-food-assessment

Sen, A. (1983). Poverty and famines: An essay on entitlement and deprivation. London and New York, New York: Oxford University Press.

Tanaka, K., Mooney, P. H., \& Wolff, B. (2014). Food insecurity and obesity in rural America: Paradoxes of the modern agrifood system. In C. Bailey, L. Jensen, \& E. Ransom (Eds.), Rural America in a globalizing world: Problems and prospects for the 2010s (pp. 642-660). Morgantown, West Virginia: West Virginia University Press.

Tauber, M., \& Fisher, A. (2002). A guide to community food projects. Venice, California: Community Food Security Coalition.

U.S. Census Bureau. (2014). United States regional population by year. In US and world population clock. Retrieved May 3, 2014, from http://www.census.gov/popclock/ 
U.S. Department of Agriculture Food and Nutrition Service [USDA FNS]. (2013). Supplemental Nutrition Assistance Program (SNAP): A short bistory of SNAP. Retrieved from http://www.fns.usda.gov/snap/short-history-snap

USDA National Institute of Food and Agriculture [USDA NIFA]. (2010, September 3). NIFA currently accepting applications for Community Food Projects [Press release]. Retrieved from http://nifa.usda.gov/ press-release/nifa-currently-accepting-applicationscommunity-food-projects

USDA NIFA. (2013). Community Food Projects Competitive Grants (CFPCGP). Retrieved from http://nifa.usda.gov/program/community-foodprojects-competitive-grant-program-cfpcgp

USDA NIFA. (2014a). Community Food Projects Competitive Grant Program: 2014 request for applications. Retrieved from http://nifa.usda.gov/sites/default/ files $/ 14$ Community $\% 20$ Foods.pdf

USDA NIFA. (2014b). National Institute of Food and Agriculture FY2014 President's budget proposal. Retrieved from http://nifa.usda.gov/sites/ default/files/resource/fy2014 president budget 1.pdf

USDA Office of Communications. (2004). Veneman awards \$4.6 million in grants for community food projects (Press Release No. 0475.04). Retrieved from http://www.usda.gov/wps/portal/usda/usdahome ?printable $=$ true $\&$ contentidonly $=$ true $\&$ contentid $=2$ $\underline{004 / 10 / 0475 . x m l}$

USDA Sustainable Agriculture Research and Education [USDA SARE]. (n.d.). SARE's four regions. Retrieved April 30, 2015, from http://www.sare.org/AboutSARE/SARE-s-Four-Regions

Ver Ploeg, M., Breneman, V., Dutko, P., Williams, R., Snyder, S., Dicken, C., \& Kaufman, P. (2012). Access to affordable and nutritious food: Updated estimates of distance to supermarkets using 2010 data (Economic Research Report No. 143). Retrieved from http://www.ers.usda.gov/media/956784/ err143.pdf

Weinfield, N. S., Mills, G., Borger, C., Gearing, M., Macaluso, T., Montaquila, J., \& Zedlewski, S. (2014). Hunger in America 2014: National report. Chicago: Feeding America. Retrieved from http://help.feedingamerica.org/HungerInAmerica Lhunger-in-america-2014-full-report.pdf

WhyHunger Network. (n.d.). Community Food Projects (CFP) database. Retrieved January 28, 2014, from http://www.whyhunger.org/cfp

Winne, M. (2008). Closing the food gap: Resetting the table in the land of plenty. Boston, Massachusetts: Beacon Press. 